\title{
IDENTIFIKASI CACAT LASAN FCAW PADA FONDASI MESIN KAPAL MENGGUNAKAN METODE ULTRASONIC TESTING
}

\author{
Fauzi Widyawati ${ }^{1^{*}}$, Lino Marano ${ }^{2}$, Fajar Nurcahyo ${ }^{3}$ \\ ${ }^{1}$ Fakultas Teknologi Lingkungan Dan Mineral Universitas Teknologi Sumbawa \\ 2Fakultas Teknologi Lingkungan Dan Mineral Universitas Teknologi Sumbawa \\ ${ }^{3}$ Departemen QA/QC PT. PAL Indonesia Persero \\ *Corresponding Author email: ${ }^{1}$ fauzi.widyawati@uts.ac.id, ${ }^{2}$ Linomarano83@gmail.com
}

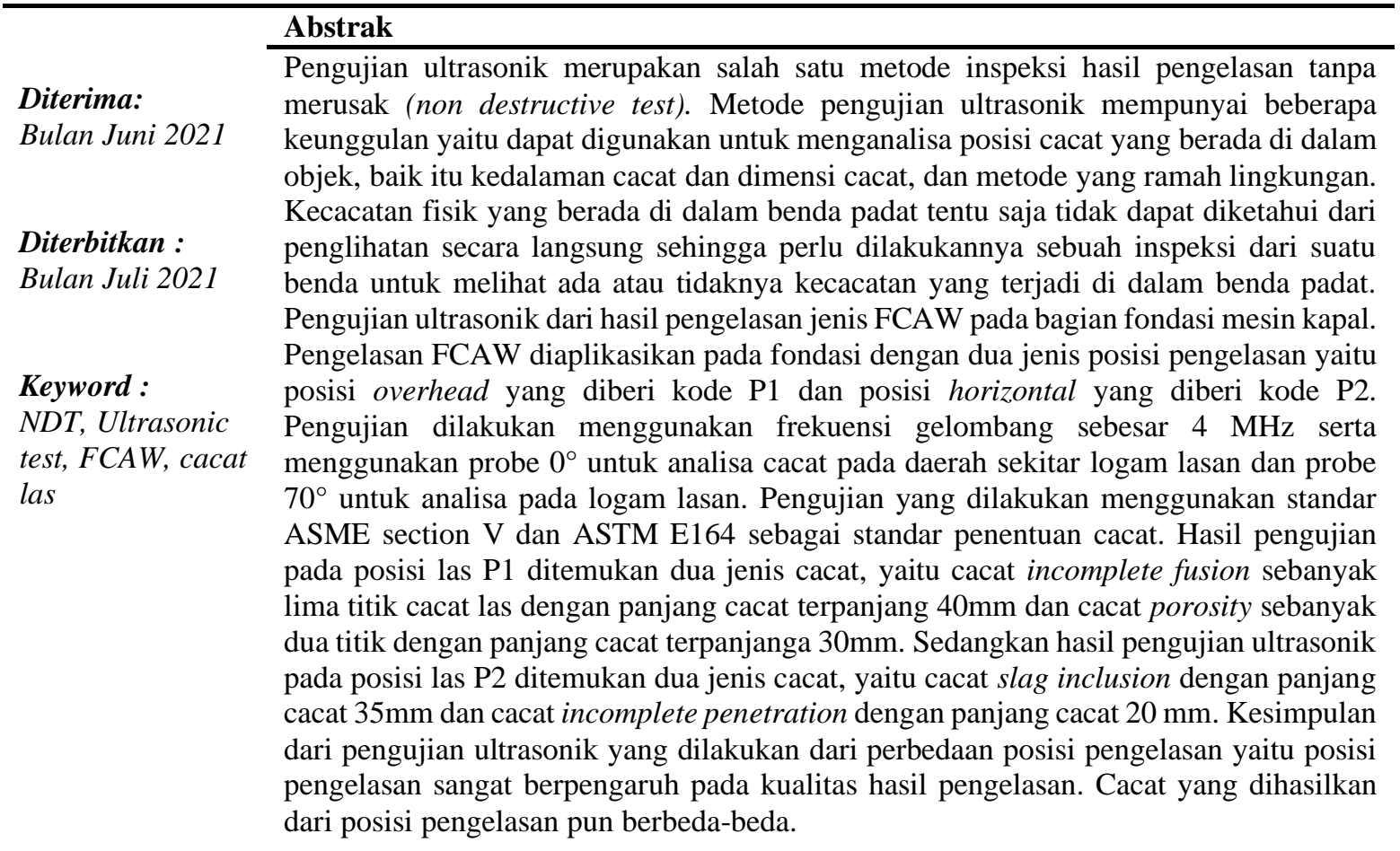

\section{PENDAHULUAN}

Teknologi pengelasan saat ini mengalami perkembangan yang cukup maju dengan berbagai metode baru yanng telah ditemukan baik yang menggunakan konvensional maupun yang numerik/digital. Hasil dari proses pengelasan memiliki banyak keunggulan, akan tetapi dalam prosesnya hasilnya tidak selalu bagus dan sering terjadi ketidaksempurnaan (cacat), hal ini dipengaruhi oleh banyak faktor baik yang disengaja ataupun yang tidak disengaja. Untuk menangani hal tersebut maka diperlukan adanya suatu inspeksi pada hasil pengelsaan agar hasil pengelasan sesuai dengan yang diinginkan dan aman untuk digunakan. Tentunya untuk melakukan inspeksi pada hasil pengelasan diperlukan suatu metode pengujian. Di dunia industri, inspeksi dilakukan menggunakan metode Non-Destructive Test (NDT) yaitu pengujian tanpa merusak benda padat yang di inspeksi (Deddy, 2002).

Non-Destructive Test (NDT) didefinisikan sebagai suatu evaluasi fisik dari suatu objek benda padat yang diuji. NDT digunakan terutama dalam dunia industri untuk mendeteksi kecacatan, retak dan rongga dalam objek yang digunakan dalam berbagai struktur dan material yang berbeda-beda jenisnya. NDT memiliki berbagai macam metode pengujian seperti pengujian liquid penetrant, pengujian magnetik partikel, pengujian eddy current, pengujian radiografi, dan pengujian ultrasonik. Setiap metode NDT mempunyai kelebihan dan kekurangan masing-masing. Beberapa metode yang tersedia hanya dapat dilakukan pengujian pada permukaan objek seperti pengujian liquid penetrant dan pengujian magnetik partikel. Metode pengujian eddy current biasa digunakan untuk inspeksi namun terbatas pada jenis material yaitu yang bersifat konduktif. Pengujian menggunakan radiografi dapat digunakan untuk inspeksi hingga internal benda tetapi mempunyai efek radiasi sinar $\gamma$ (gamma) yang berbahaya bagi manusia. Dalam NDT, pengujian menggunakan gelombang ultrasonik lebih populer digunakan karena pengujian tersebut dapat digunakan untuk berbagai jenis material, dapat menjangkau cacat di dalam objek, dan ramah terhadap lingkungan (Thoriq, 2015). 
Dalam suatu kontruksi yang dilakukan proses pengelasan, perlu dilakukan suatu inspeksi pada hasil lasan menggunakan metode NDT. Tujuannya untuk mengetahui kemungkinan munculnya cacat yang timbul akibat proses pengelasan. Di industri perkapalan, banyak digunakan metode pengelasan FCAW dan ada beberapa posisi pengelasan. Posisi pengelasan ditentukan berdasarkan konstruksi bagian kapal yang akan dilas. Beberapa posisi pengelasan antara lain posisi horizontal dan overhead. Posisi pengelasan mempengaruhi kualitas hasil lasan sehingga bisa jadi menimbulkan jenis cacat yang berbeda-beda.

Oleh sebab itu, pada penelitian ini dilakukan analisa cacat hasil pengelasan menggunakan metode pegujian ultrasonik. Pengujian ultrasonik dilakukan pada material hasil lasan dengan perbedaan posisi pengelasan. Penelitian ini dilakukan untuk menganalisa jenis cacat pada bagian fondasi mesin yang posisinya ada di bagian lambung kapal.

\section{LANDASAN TEORI}

\section{Pengelasan}

Pengelasan merupakan salah satu bagian yang tak terpisahkan dari proses manufakrur. Proses pengelasan prinsipnya dalah menyambungkan dua atau lebih komponen, lebih tepat ditujukan untuk merakit beberapa komponen menjadi suatu bentuk mesin. Komponen yang dirakit mungkin saja berasal dari produk hasil pengecoran, pembentukan atau pemesinan, baik dari logam yang sama maupun berbeda-beda. Pengelasan adalah salah satu teknik penyambungan logam dengan cara mencairkan sebagian logam induk dan logam pengisi dengan atau tanpa tekanan dan dengan atau tanpa logam tambahan dan menghasilkan sambungan yang kontinu (Hery, 2006).

\section{Pengelasan FCAW (Flux Cored Arc Welding)}

Pengelasan FCAW merupakan salah satu jenis las listrik yang proses kerjanya memasok filler elektroda atau kawat las secara mekanis terus menerus ke dalam busur listrik. Kawat las atau elektroda yang digunakan untuk pengelasan FCAW terbuat dari logam tipis yang digulung cylindrical kemudian dalamnya di isi dengan flux yang sesuai dengan kegunaannya. Dalam pengelasan FCAW ini sumber energi menggunakan arus listrik DC atau AC yang diambil dari pembangkit listrik atau melalui trafo dan atau rectifier. Pengelasan FCAW umumnya menggunakan gas $\mathrm{CO}_{2}$ atau campuran $\mathrm{CO}_{2}$ dengan Argon sebagai gas pelindung. Tetapi untuk menghindari logam las terkontaminasi udara luar atau menghindari porositas maka harus dilakukan pemilihan fluks yang mengandung mempunyai sifat pengikat oxygen atau deoxidizer (Jones, 2015).

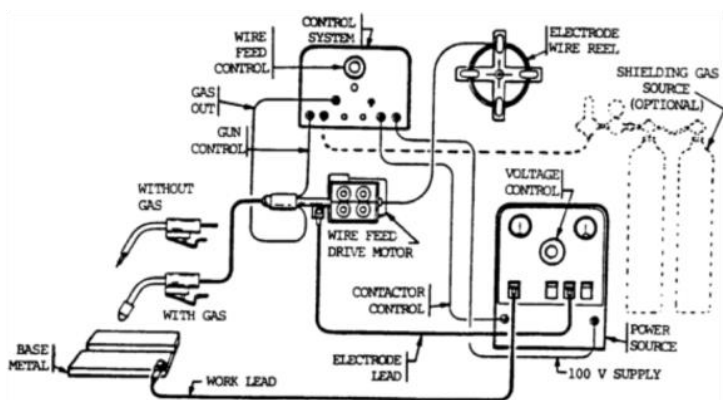

Gambar 1. Skema Proses FCAW

Metode FCAW banyak digunakan dalam proses pengelasan karena memiliki sifat-sifat sebagai berikut :

a. Las FCAW memiliki sifat metalurgi las yang bisa dikontrol dengan pemilihan flux.

b. Metode FCAW mempunyai produktivitas lasan yang tinggi karena elektroda las kontinu.

c. Saat proses pengelasan, flux memberikan perlindungan pada kawat las dengan membentuk selubung gas dan lapisan slag.

d. Pengelasan FCAW dapat digunakan untuk berbagai macam posisi pengelasan tanpa menimbulkan masalah lack of fusion.

\section{Posisi Pengelasan}

Posisi atau sikap pengelasan adalah pengaturan posisi atau letak gerakan elektroda las. Posisi pengelasan yang digunakan biasanya tergantung dari letak kampuh atau celah benda kerja yang akan dilas. Adapun pada gambar 2 merupakan posisi pengelasan terdiri dari posisi pengelasan di bawah tangan (down hand), posisi pengelasan mendatar (Horizontal), posisi pengelasan tegak (vertical) dan posisi pengelasan di atas kepala (over head).

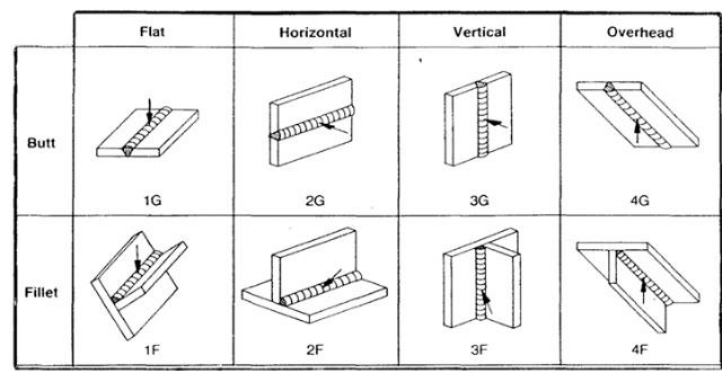

Gambar 2 Jenis Jenis Posisi Pengelasan

\section{Cacat Hasil Pengelasan}

Cacat las merupakan keadaan yang mengakibatkan turunnya kualitas hasil dari lasan. Cacat yang terjadi pada umumnya mempengaruhi nilai kekuatan dari sambungan las, sehingga hasil yang didapat tidak sesuai dengan nilai konstruksi yang diinginkan. Adapun jenis-jenis cacat las yang terdapat pada konstruksi pengelasan antara lain undercut, porosity, slag inclusion, incomplete penetration, incomplete fusion, over spatter, hot crack, dan cold cracking (Salmon, 1992). 


\section{Pengujian Ultrasonik}

Pengujian ultrasonik merupakan salah satu metode pengujian dari Non Destructive Testing (NDT) yang menggunakan media gelombang ultrasonik (gelombang suara) yang mempunyai frekuensi tinggi $>20 \mathrm{Khz}$. Pengujian ultrasonik dapat digunakan untuk mendeteksi dimensi benda kerja dan kecacatan atau porositas pada benda kerja (Sharma, 2018).

Adapun komponen-komponen yang terdapat dalam pengujian ultrasonik antara lain (Debora, 2013):

a. Couplant

Tujuan utama pemakaian kuplan adalah untuk menyediakan lintasan suara yang memadai antara transducer dan permukaan benda uji. Suatu kuplan harus secara efektif membasahi atau secara sempurna menghubungkan permukaan transducer dan benda uji.

b. Probe

Probe adalah alat yang digunakan menyalurkan gelombang suara dari transducer ke benda uji. Probe mempunyai tiga jenis yaitu probe normal, probe sudut dan probe kembar.

c. Blok Standar

Dalam pengujian ultrasonik, diskontinuitas biasanya dibandingkan dengan sebuah standar referensi. Standar tersebut dapat berupa sebuah blok referensi atau sekumpulan blok-blok yang diperlukan untuk pengujian tertentu. Blok referensi terdapat dalam bentuk dan ukuran yang berbeda.

Gelombang ultrasonik dapat ditimbulkan dari probe. Gelombang yang diberikan terjadi karena perubahan energi listrik ke energy mekanik dari transducer melalui efek piezoelektrik. Efek piezoelektrik ini merupakan efek reversible artinya jika energi listrik menghasilkan mekanik maka juga sebaliknya mekanik menghasilkan energi listrik. Efek ini berguna untuk mendapatkan frekuensi yang sesuai (Cunfu, 2016).

\section{METODE PENELITIAN}

\section{Alat dan Bahan Penelitian}

Adapun alat digunakan dalam penelitian ini antara lain alat UT Flaw Detector merk SIUI CTS9005, blok kalibrasi IIW-V1, blok kalibrasi IIW-V2, BCB (Basic Calibration Block), probe sudut $0^{\circ}$ dan $70^{\circ}$, penggaris besi, kuas, wadah, spidol, dan kain lap. Sedangkan bahan yang digunakan adalah bubuk CMC (Carboxy Methyl Celulose) dan air.

\section{Persiapan Alat dan Bahan}

Permukaan benda kerja yang akan di inspeksi dibersihkan dari debu, oli, dan pengotor lainnya. Dipersiapkan alat-alat yang akan digunakan termasuk mesin uji ultrasonik dan formulir inspeksi.
Cairan couplant yang digunakan sebagai bahan pengujian dibuat dengan mencampurkan air secukupnya dengan bubuk CMC dalam wadah sampai menghasilkan cairan dengan kekentalan yang pas.

\section{Kalibrasi Alat Uji Ultrasonik}

Untuk mengecek bahwa alat bekerja dengan baik, dilakukan kalibrasi pada alat sebelum digunakan. Tujuan dilakukannya kalibrasi yaitu untuk memastikan keakuratan alat dalam pembacaan cacat. Dilakukan kalibrasi pertama menggunakan blok IIW-V1 dan blok IIW-V2 untuk mengecek akurasi probe dan alat. Kemudian kalibrasi kedua menggunakan blok BCB (Basic Calibration Block) untuk pembuatan pengaturan DAC guna untuk pengerjaan pada sambungan pengelasan sesuai standar ASME section v. Frekuensi gelombang yang digunakan saat kalibrasi yaitu menggunakan frekuensi $4 \mathrm{MHz}$ yaitu frekuensi maksimal pada penggunaan standar ASME, frekuensi gelombang ini juga yang akan digunakan saat pengujian pada benda kerja.

\section{Pengujian Ultrasonik}

Benda kerja yang akan diuji merupakan hasil pengelasan dengan perbedaan 2 posisi. Benda P1 yaitu hasil lasan posisi overhead dan benda $\mathrm{P} 2$ yaitu hasil lasan posisi horizontal. Setelah mempersiapkan alat dan bahan, kemudian dilakukan pengujian ultrasonik pada benda kerja menggunakan probe sudut $70^{\circ}$ dan $0^{\circ}$. Prosedur pertama yaitu dilakukan pengolesan cairan kuplan secara marata pada benda kerja menggunakan kuas, selanjutnya melakukan scanning menggunakan alat ultrasonik dengan menempelkan probe pada benda kerja dan gerakkan secara perlahan dengan gerakan maju mundur agar rambatan gelombang mengenai seluruh daerah sambungan lasan.

\section{Prosedur Penentuan Cacat}

Ketika dilakukan prosedur scanning pada benda kerja, hasil scanning akan ditampilkan pada layar perangkat berupa pulsa indikasi. Jika pulsa yang ditampilkan mengindikasikan cacat, probe harus didiamkan hingga pulsa indikasi stabil dan saat bersamaan menampilkan informasi jarak antara ujung probe dengan cacat dalam satuan milimeter diantaranya surface distance, angular distance, dan depth from surface (kedalaman). Kemudian menentukan posisi cacat pada benda kerja menggunakan data jarak yang ditampilkan perangkat dan melakukan pengukuran secara langsung menggunakan penggaris berdasarkan data jarak tersebut. Setelah posisi cacat ditemukan, selanjutnya menandai posisi dan panjang cacat menggunakan spidol dan mendata kedalaman cacat berdasarkan data yang ditampilkan perangkat guna untuk proses perbaikan sambungan pengelasan.

Pada pengujian ultrasonik, dilakukan kalibrasi alat sebelumnya yang mengacu pada standar ASME. 
Penggunaan standar ASME ini untuk mendeteksi diskontinuitas yang nilainya lebih besar dari $20 \%$ tingkat referensi pada scan A maka akan di selidiki lebih lanjut, sedangkan untuk cacat yang nilainya kurang dari $20 \%$ maka tidak akan di selidiki lebih lanjut. Dalam hal ini operator dapat menentukan bentuk, identitas dan lokasi dari semua ketidak sempurnaan (cacat) tersebut dan menilainya dalam hal standar penerimaan yang diberikan dalam hal:

a. Indikasi yang ditandai sebagai crak, lack of fusion atau incomplete penetration maka material dinyatakan reject tanpa memperhatikan panjang cacat.

b. Discontinuity diluar ketentuan diatas pada (a) maka tidak bisa diterima jika indikasi melebihi amplitudo referensi dan panjangnya melebihi ketentuan dibawah ini :

1) $1 / 4$ inci $(6 \mathrm{~mm})$ for t up $3 / 4$ inci ( $19 \mathrm{~mm})$

2) $1 / 3 \mathrm{t}$ from $3 / 4$ inci to $21 / 2$ ( $19 \mathrm{~mm}$ to $57 \mathrm{~mm}$ )

3) $3 / 4$ Inci $\left(19 \mathrm{~mm}\right.$ ) for $(\mathrm{t})$ over $2 \frac{1 / 4}{4}$ Inci ( 57 $\mathrm{mm}$ )

Dimana $\mathrm{t}$ adalah ketebalan dari lasan. Untuk pengelasan dua buah material yang memiliki ketebalan berbeda pada hasil lasannya maka t adalah ketebalan paling kecil dari kedua material tersebut.

Benda kerja yang akan dianalisa memiliki ketebalan $18 \mathrm{~mm}$. Berdasarkan ketebalan tersebut, maka probe yang digunakan adalah probe sudut $70^{\circ}$ dan probe $0^{\circ}$. Untuk pemilihan sudut probe ditentukan oleh persyaratan dari prosedur atau code, desain sambungan las, dan konfigurasi spesimen. Tabel berikut memperlihatkan besarnya sudut probe yang sesuai untuk pengujian las pada material dengan ketebalan bervariasi. Jika tebal benda bertambah besar, sebaiknya dipakai probe dengan sudut yang lebih kecil.

Tabel 1. Ketentuan Pemilihan Sudut Probe

\begin{tabular}{|c|c|c|}
\hline \multicolumn{3}{|c|}{ Untuk Capping Las yang dihilangkan pada } \\
Kedua Sisi \\
\hline $\begin{array}{c}\text { Tebal Pelat } \\
(\text { Inchi })\end{array}$ & Sudut Probe $\left({ }^{\mathrm{o}}\right)$ & Jarak Skip (Inchi) \\
\hline $0,2-0,6$ & 80 & $2,2-6,6$ \\
\hline $0,6-1,2$ & 70 & $3,2-6,6$ \\
\hline $1,2-2,4$ & 60 & $4,2-8,4$ \\
\hline$>2,4$ & 45 & 4,8 dan di atasnya \\
\hline Untuk Capping Las yang tidak dihilangkan \\
\hline $0,2-0,8$ & 80 & $2,2-8,8$ \\
\hline $0,81,6$ & 70 & $4,4-8,8$ \\
\hline$>1,6$ & 60 & 5,6 dan di atasnya \\
\hline
\end{tabular}

\section{HASIL DAN PEMBAHASAN}

Pengujian Ultrasonik dilakukan pada bagian fondasi mesin kapal dengan jenis material ST-37 dan mempunyai ketebalan $18 \mathrm{~mm}$ yang terbagi menjadi dua bagian. Bagian pertama merupakan hasil pengelasan posisi overhead yang diberi kode "P1" dan terdapat dua sambungan yang akan dianalisa, sambungan 1 memiliki panjang $460 \mathrm{~mm}$, dan sambungan 2 memiliki panjang $6100 \mathrm{~mm}$. Sedangkan bagian kedua merupakan hasil pengelasan posisi horizontal yang diberi kode "P2" dan terdapat 5 sambungan yang akan dianalisa, sambungan 1 memiliki panjang $9516 \mathrm{~mm}$ sedangkan sambungan 2 sampai sambungan 5 memiliki panjang $450 \mathrm{~mm}$.

Pengujian Ultrasonik menggunakan probe $70^{\circ}$ untuk analisa cacat pada logam lasan dan probe $0^{\circ}$ untuk analisa cacat pada daerah sekitar logam lasan. Teknik rambatan gelombang yang digunakan dalam penelitian ini adalah teknik gema yaitu teknik untuk mengetahui cacat dari kecepatan amplitudo gelombang dan waktu cepat rambat yang diterima probe. Pengujian ultrasonik pada penelitian ini menggunakan standar LR (Lloyd's Register) yang mengacu pada standar ASME.

Setelah dilakukan pengujian ultrasonik, didapatkan hasil pengujian yaitu bagian P1 ditemukan 7 cacat pada sambungan 2, sedangkan bagian P2 ditemukan 2 cacat pada sambungan 1dengan ukuran dan jenis yang berbeda-beda.

Tabel 1 Hasil Pengujian Ultrasonik Pada Bagian P1 Sambungan 2

\begin{tabular}{|l|c|c|c|}
\hline No. & Length & $\begin{array}{c}\text { Depth From } \\
\text { Surface } \\
(\mathbf{m m})\end{array}$ & $\begin{array}{c}\text { Discontinuity } \\
\text { Type }\end{array}$ \\
\hline 1 & 40 & 8 & IF \\
\hline 2 & 20 & 8 & IF \\
\hline 3 & 20 & 5 & IF \\
\hline 4 & 30 & 3 & POR \\
\hline 5 & 25 & 6 & POR \\
\hline 6 & 15 & 10 & IF \\
\hline 7 & 25 & 10 & IF \\
\hline Keterangan : & \\
\hline $\begin{array}{l}\text { IF } \\
\text { IP Incomplete Fusion } \\
\text { POR Incomplete Penetration } \\
\text { SI Porosity } \\
\text { CR Slag Inclusion } \\
\text { = Crack }\end{array}$ \\
\hline
\end{tabular}

Pada tabel 1 hasil inspeksi menunjukkan cacat lasan pada bagian P1 paling banyak terbentuk cacat Incomplete Fusion (IF) sebanyak 5 titik cacat dan Porosity (POR) 2 titik cacat. Panjang cacat yang terbentuk paling panjang yaitu $40 \mathrm{~mm}$ pada cacat incomplete fusion dan $30 \mathrm{~mm}$ pada cacat porosity. 
Merujuk pada sumber referensi, cacat incomplete fusion terbentuk karena posisi sudut kawat las salah, ampere terlalu rendah, atau travel speed terlalu tinggi. Sedangkan cacat porosity terbentuk akibat arus pengelasan terlalu rendah, travel speed terlalu tinggi, atau adanya zat pengotor pada benda kerja (karat, minyak, air dll). Berdasarkan analisa tersebut cacat bisa diminimalisir atau dihindari dengan cara memastikan tidak ada pengotor dalam benda kerja, memperbaiki posisi sudut elektroda, dan mengatur ampere dan travel speed sesuai dengan WPS (Welding Procedure Specification).

Tabel 2 Hasil Pengujian Ultrasonik Pada Bagian P2 Sambungan 1

\begin{tabular}{|l|c|c|c|}
\hline No. & Length & $\begin{array}{c}\text { Depth From } \\
\text { Surface } \\
(\mathbf{m m})\end{array}$ & $\begin{array}{c}\text { Discontinuity } \\
\text { Type }\end{array}$ \\
\hline 1 & 35 & 12 & SI \\
\hline 2 & 20 & 17 & IP \\
\hline Keterangan : \\
\hline IF = Incomplete Fusion \\
IP = Incomplete Penetration \\
POR = Porosity \\
SI = Slag Inclusion \\
CR = Crack \\
\hline
\end{tabular}

Pada tabel 2 hasil inspeksi menunjukkan cacat lasan pada bagian P2 terbentuk satu cacat Incomplete Penetration (IP) dengan panjang cacat $35 \mathrm{~mm}$ dan satu cacat Slag Inclusion (SI) dengan panjang cacat $20 \mathrm{~mm}$. Merujuk pada sumber referensi dari buku, cacat incomplete penetration terbentuk karena jarak gap atau root opening terlalu lebar, jarak elektroda atau busur las terlalu tinggi, ampere terlalu kecil atau travel speed terlalu tinggi. Sedangkan cacat slag inclusion terbentuk akibat proses pembersihan slag yang kurang baik sehingga tertumpuk oleh lasan, ampere terlalu rendah, busur las terlalu jauh atau sudut pengelasan yang salah. Berdasarkan analisa tersebut cacat bisa diminimalisir atau dihindari dengan cara memastikan lasan bersih dari slag sebelum mengelas ulang dan menyesuaikan ampere, travel speed dan sudut kampuh sesuai dengan WPS (Welding Procedure Specification).

Dimensi dari cacat yang ditemukan dapat diketahui dari beberapa informasi yang ditampilkan perangkat salah satunya informasi kedalaman cacat, dan panjang cacat ditentukan dari panjang jarak antara posisi awal ditemukan cacat hingga indikasi cacat berakhir. Sedangkan penentuan jenis cacat ditentukan dengan melakukan analisa mengenai jenis-jenis cacat yang sering terjadi pada metode pengelasan FCAW, dan menganalisa kesamaan bentuk dari beberapa jenis cacat dengan posisi dan bentuk cacat yang ditemukan di dalam logam lasan.

Secara umum beberapa cacat yang telah ditemukan terbentuk karena ketidaksesuaian prosedur pengelasan dengan WPS (Welding Procedure Specification). WPS berfungsi sebagai acuan prosedur sebelum proses pengelasan dan sebagai kontrol inspeksi. WPS menjadi kontrol inspeksi karena pada WPS tersebut tercantum metode pengelasan, dimensi kampuh, jenis elektroda, pengaturan voltase dan ampere, serta posisi pengelasan. Saat inspeksi dilakukan dan ditemukan suatu cacat maka WPS menjadi penting untuk menelusuri proses yang sudah dilakukan dan menjadi dasar saat analisa hasil lasan.

\section{PENUTUP}

\section{Kesimpulan}

Berdasarkan hasil dari penelitian yang dilakukan maka didapatkan kesimpulan sebagai berikut:

1. Posisi pengelasan sangat berpengaruh terhadap kualitas hasil lasan. berdasarkan inspeksi ultrasonik pada posisi sambungan las P1 (overhead) terdapat tujuh cacat yang ditemukan, yaitu lima cacat incomplete fusion dan dua cacat porosity. Sedangkan pada posisi sambungan las P2 (horizontal) terdapat dua cacat yang ditemukan, yaitu satu incomplete penetration dan satu cacat slag inclusion.

2. Berdasarkan analisa cacat pada hasil pengelasan diketahui penyebab terjadinya cacat secara umum yaitu akibat ketidasesuaian prosedur pengelasan yang terdapat pada WPS (Welding Procedure Specification) dan perbedaan posisi sambungan las yang dapat mengakibatkan jenis cacat yang berbeda.

\section{REFERENSI}

A. Sharma, A. K. (2018). Ultrasonic Testing for Mechanical Engineering Domain: Present and Future Perspective. India: International Journal of Research in Industrial.

Abderrahim Bezza, P. D. (2016). Remarks on Defect Detection in a Two Dimensional Structure with Welded Joints. HAL.

Bintoro, G. A. 1999. Dasar-Dasar Pekerjaan Las Jilid 1. Penerbit Kanisius. Yogyakarta.

Cunfu He, Y. W. (2016). Design and Fabrication of Air-Based 1-3 Piezoelectric Composite Transducer for Air-Coupled Ultrasonic Applications. China: Hindawi. 
Debora, F. (2013). Pengukuran Ketebalan Serta Posisi Cacat pada Sampel Carbon Steel dan Stainless Steel dengan Metode Ultrasonic Testing. Malang: Universitas Sriwijaya.

Deddy Kristanto, Wing Hendroprasetyo AP. ST. M. Eng. 2002. Studi Penentuan Panjang dan Kedalaman Retak Sambungan Las pada Konstruksi Kapal Menggunakan Pengujian Ultrasonik Dengan Varias Frekuensi dan Ukuran Kristal dan Dengan Variasi Kondisi Permukaan Coating dan Uncoating. Surabaya

Hastuti, Farida. 2010. Analisa Pengaruh Pengelasan FCAW Pada Sambungan Material Grade A dengan Material Grade DH 36. Tugas Akhir Jurusan Teknik Kelautan, FTK, ITS, Surabaya.

Hery Sonawan. 2006. Pengantar Untuk Memahami Proses Pengelasan Logam. Bandung: Alfabeta.

https://id.scribd.com/document/436375392/JenisCacat-Las-Dan-Penyebabnya-Serta-CaraMengatasinya/ https://www.tws.edu/blog/welding/6-fcaw-swelding-defects-and-how-to-avoid-them/

Mgonja, C. T. (2017). Evaluation on Use of Industrial Radiography for Weld Joints Inspection in Tanzania. Tanzania: International Journal of Mechanical Engineering and Technology (IJMET).

Muhammad Thoriq Wahyudi. 2015. Modul Pengembangan Materi Pembelajaran Mata Kuliah Teori NDT. Surabaya: Politeknik Perkapalan Negeri Surabaya. Non-Destructive Testing (NDT) Guidance Document: An Introduction to NDT Common Methods. (2015). Roll Royce.

R. I. Romanishin, I. M. (2018). Processing of Backscattered Signal in Ultrasonic Testing. Pleiades Publishing, 395-396.

Salmon Charles G. 1991. Desain dan Perilaku Struktur Baja. Jakarta: Erlangga.

Whidarto. 2006. Petunjuk Kerja Las. Jakarta: PT. Pradnya Paramita.

Wiryosumarto, Harsono., Okumura, Toshie. 1996. Teknologi Pengelasan Logam. Jakarta: PT. Pradnya Paramita. 